\title{
HOSPITALITY AND THE NATION IN MARY WOLLSTONECRAF'S A SHORT RESIDENCE IN SWEDEN, NORWAY, AND DENMARK
}

In the summer of 1795, when Mary Wollstonecraft journeyed to Scandinavia, she was disillusioned with human society and the possibility of meaningful relation with others. She had recently been in Paris, where she had seen many of her moderate revolutionary friends executed under Robespierre's Reign of Terror, and by the time of her arrival in Scandinavia her unsatisfactory relationship with Gilbert Imlay was coming to an end. The book that resulted from this journey, A Short Residence in Sweden, Norway, and Denmark, is remarkable for its critique of sovereignty and the reification of difference inherent to the construction of national borders and the drives of commercial exchange. The article argues that Wollstonecraft insists upon openness to the people and cultures she encounters through configuring epistemology as a twin process of experiential contact and sceptical inquiry. This a process that remains inherently and necessarily ethical because it resists the structures of tyranny, domination, and control, which Wollstonecraft perceives to be afflicting lateeighteenth-century Europe, whilst simultaneously allowing for a re-conception of politics and justice according to the demands both of the present and the not-yet-formalised future.

K EY W O R D S Travel Writing, Hospitality, Nation, Commerce, Epistemology, Politics, Justice.

In late June 1795, Mary Wollstonecraft travelled to Scandinavia with her maid and her infant daughter. Most of Europe was then at war with France, and travel at this time was generally thought to be a precarious affair. During the three and a half months in which she travelled from Gothenburg in Sweden, across the Norwegian border to Halden, Skagerak, Larvik, and Risor, then via Oslo into Denmark, Schleswig and finally to Hamburg, Wollstonecraft wrote a series of letters to her lover Gilbert Imlay, on whose business she was travelling as envoy and legal representative. Although their relationship was at an end by the time of Wollstonecraft's departure from England, she made the journey as Imlay's officially appointed legal representative in an attempt to recover a stolen ship containing a large amount of silver and plate. ${ }^{1}$ Upon her return to England, Wollstonecraft rewrote these private letters into the epistolary travel narrative entitled $A$ Short 
Residence in Sweden, Norway, and Denmark, removing any direct reference to Imlay as addressee of the letters and similarly any reference to the commercial aims of the journey.

The published text resulting from her journey and the rewriting of the private letters to Imlay takes up the concerns of Wollstonecraft's earlier political treatise, Vindication of the Rights of Woman. In the Scandinavian letters, the call in the earlier text for British men to prove their strength and compassion by creating a democracy based on friendship and a respect for difference becomes transposed into a concern with the roles of difference and the foreign in the creation of communities, cultures, and nations. In Short Residence, as I will argue, Wollstonecraft insists upon openness to the foreign as a site of difference and the non-determined, and as a potential means of regeneration and improvement. This necessarily requires the relinquishing of control over self and others via a certain degree of selfexpropriation. Indeed the construction of A Short Residence as a series of letters in the epistolary mode specifically foregrounds this space of difference, whereby the open address becomes the means by which a non-determined otherness (the foreign) can be heard as a response.

Some scholars have noted the use of the epistolary mode in A Short Residence as a deliberate strategy by Wollstonecraft that aims to bring the personal into the realm of the public and the political. Mary Favret argues, for example, that the erasure of Imlay as specific addressee in the published letters specifically denotes a movement towards a public world of correspondence in which Wollstonecraft uses the forms of both sentimental memoir and philosophical essay with the aim of seducing a larger reading audience. Favret notes that this shift, from the personal to the public, is in fact 'a common strategy of "open letters", whereby political critiques masked in the form of a letter to a king or ruler were published most often as pamphlets, or in journals and newspapers. As such, Favret writes, 'these open letters invite a wide audience to participate in the letter-writer's outcry'. In this configuration, the letters become a form of self-performance that is dependent upon the recognition by the wider audience of the writer's 'dramatis personae', such that the identity figured by the letters comes to be a performance that is, as Favret argues, 'communal and cultural'. ${ }^{3}$ Yet, as Gregory Dart astutely notes, A Short Residence only provides 'one half of the dialogue', so that despite Dart's claim that the openness of the address dramatises the 'culpable non-responsiveness of her correspondent', I suggest that the shift to public response, noted by Favret, as well as the provision of only one side of the address, as noted by Dart, together highlight the importance of Wollstonecraft's open address as a non-determined ethical gesture that both invites and demands a response. ${ }^{4}$ In other words, the openness of her address invites the other to respond both as a reception from as well as a direction to the foreign.

This dual process of invitation and response is similar to that enacted in Rights of Woman through Wollstonecraft's critical analysis of gender in key British and French texts, in which she creates spaces for the insertion of difference into eighteenth-century British notions of democracy. Her preoccupation with the open- 
ness of self and society to non-determined change, and to the future as difference and context, necessitates in A Short Residence, just as it did in Rights of Woman, the question of how to negotiate self/selves-in-society without foreclosing on alterity and the possibility for change (the political) and the respect for difference (the ethical). In Rights of Woman, Wollstonecraft had argued specifically that gendered identity was very much a social construct by suggesting that both girls and boys 'would play harmlessly together, if the distinction of sex was not inculcated long before nature makes any difference'. In A Short Residence, this concern with the construction of gendered identity is shifted largely to one that focuses on the construction of national identities via state and juridical systems, and specifically the ways in which the different cultures and societies she encounters along the way can provide possible examples for a British society that Wollstonecraft sees as desperately in need of improvement.

In this sense, the later text foregrounds the notion of hospitality, not only I suggest as an openness to different cultures and peoples, but similarly as a means of placing the self in question, either the individual self or the communal or national self. In this sense, my interest in the way that Wollstonecraft holds open a space for radical otherness in A Short Residence, specifically as an ethical gesture that emphasises knowledge as embedded and contextual, diverges from much scholarship on this text which, for the most part, tends to emphasise the roles of sentiment and feeling in the construction of the Wollstonecraftian narrative. To a certain extent, Wollstonecraft's use of the sentimental mode in her political tracts and certainly in the Scandinavian letters allows a form of contact and exposure in a way that generates, as I will show, the sorts of openings towards difference necessary for the ethical encounter. The contact generated from direct engagement through feeling and the openness generated from sceptical inquiry both operate in a twin process that effectively refuses the reduction of alterity to the same.

My argument therefore contradicts earlier feminist readings of A Short Residence which emphasise the letters as either a journey towards self-discovery or as the expression of feminine desire, and which therefore read the letters in terms of self-expression and self-arrival. Eleanor Ty, for example, sees in Wollstonecraft's text a search for 'something more' whereby the inscription of 'the female self and her passions' transgresses physical and emotional boundaries as a means of articulating a freedom that is distinctly personal. ${ }^{6}$ Jeanne Moskal similarly wants to affirm an empowered but somewhat essentialised femininity in the letters with her insistence on their figuration of nature-as-nurture as a means of transforming a sterile and masculine sublime into a fertile and material sublime. For Moskal, A Short Residence is all about mothers and daughters. She argues that Wollstonecraft, in contrast to Burke's 'contempt for the maternal breast as part-object ... constructs an ideal of the whole object, the good Mother Nature', and that this identification with nature as nurture generates Wollstonecraft's speaking voice and allows it to be heard. ${ }^{7}$ In these readings the focus on self-expression and selfempowerment would disable the openness required for hospitality to the foreign 
simply through the circumscription and return of all that is strange and different to the parameters of the self (either the personal self or the national self).

Even more recent readings that aim to move away from Moskal and Ty's psychoanalytic re-figurations of feminine desire as power, nevertheless focus on the way in which Wollstonecraft's use of the sentimental narrative transforms, in $A$ Short Residence, personal suffering into a force for social progress. Deborah Weiss's astute reading of the Scandinavian letters as an illustration of the ways in which 'the feelings occasioned by oppression are a source of strength, deep reasoning, and socially productive intellectual work', whilst highlighting an important aspect of the text in the way it draws attention to the use of women's suffering in the construction of the eighteenth-century British 'Man of Feeling', configures the aims of Wollstonecraft's travel narrative as perhaps more determined than its insistence on openness towards the foreign would allow. ${ }^{8}$

Nevertheless, Weiss's reading of the Scandinavian letters draws attention to the difficult co-situating of the political (which requires determined aims) and the ethical (which requires their relinquishing), even though she is not specifically concerned with the latter. By focussing on the ethical relation in Wollstonecraft's A Short Residence, specifically via her insistence on openness to difference and hospitality to the foreign, I will further argue that Wollstonecraft resists the colonising imperatives of which she has been accused by various critics. Cynthia Richards suggests that the undertaking of the journey to Scandinavia as a commercial venture and as a means to win back the heart of Wollstonecraft's disaffected lover configures $A$ Short Residence as a conquest narrative with calculated ends, not the least of which was, as William Godwin has famously remarked in his memoirs of Wollstonecraft, the writing of a text that was 'calculated to make a man in love with its author. ${ }^{9}$ Ty similarly argues that Wollstonecraft effectively colonises the landscape of her journey by describing it in phrases that turn it into 'something akin to an English countryside', whereby Wollstonecraft, as the viewer, can 'control her relation and responses to the landscape in a way that she cannot control her heart'. ${ }^{\circ}$

Yet, the criticism by scholars such as Richards, Ty, and Raoul Grandqvist that Wollstonecraft depicts in the Scandinavian letters an inherently imperialist project of commercial recovery, colonial exploration, and the acquisition of knowledge through what is seen as a colonising gaze would seem to be destabilised by the letters' consistent emphasis on the narrator's marginal position as a foreigner dependent upon the hospitality of strangers, as well as its simultaneous insistence on openness to the foreign. ${ }^{11}$ It is for this reason therefore that I want to examine Wollstonecraft's use of the epistolary mode not as an invitation to identify with the author through the sentimental narrative, nor as a means of transforming private suffering into social analysis. Whilst sentiment is certainly an important aspect of Wollstonecraft's mode of engagement with the world, in this essay I am specifically concerned with the way in which it engenders ethical response, not through self-exploration and self-expression, as others have 
argued, but rather through placing the self in question and inviting the (nondetermined) response of the other.

Jacques Derrida's work on hospitality and the stranger is useful here, I suggest, as a means of providing a way of thinking about Wollstonecraft's persistent questioning and self-expropriation as a disruption of the acquisitive drives of commerce through opening out to the non-determined response of otherness, and in particular to the otherness of the reader. Derrida notes in his work on hospitality and the stranger that in many of Plato's Socratic dialogues it is often the foreigner who questions, who 'shakes up the threatening dogmatism of the paternal $\log o s^{\prime}{ }^{12}$ Derrida is concerned primarily with the self's confrontation with the foreigner as a source of alterity, that is, as 'the one who, putting the first question, puts me in question'. ${ }^{13}$

This becomes a persistent theme throughout A Short Residence, where hospitality to the foreigner is depicted both on the everyday level of kindness to strangers, as a conditional form of hospitality, as well as on the more radical level of self-disruption and self-questioning, as hospitality in its unconditional form. As Derrida argues, without the structures of the everyday, as those that govern the state and the law, 'concrete politics and ethics, including a history, evolutions, actual revolutions, advances - in short, a perfectibility' would not be possible. ${ }^{14}$ By thus reading the Scandinavian letters with attention to the co-situating of the unconditional and the absolute within the structures of the everyday, I will illustrate the way in which Wollstonecraft gestures, in A Short Residence, towards a means of reconfiguring the socio-political systems of her era in order to insist upon a notion of knowledge as intrinsically contextual and embedded, thus giving rise to a system of justice that is intrinsically subject to the demands of the ethical relation.

\section{Borders}

A Short Residence places, from the very outset, the position of its narrator as marginal both to the lands she is visiting (in that she begins by losing her way) and to her homeland (in that she is a British woman travelling alone). This effectively destabilises the authority of the speaking voice and begins to place the narratorial self in question. Moreover, given that the final text is published in England and therefore primarily addressed to an English-speaking audience, A Short Residence enacts a double expropriation as a twin movement, whereby the narrator is not only aware of her own foreignness as she travels throughout Scandinavia, but similarly allows the foreignness of the other peoples and cultures she encounters to place her own suppositions in question. The open address similarly invites a response from a (conditionally) non-determined other, in the form of the reader, thereby opening the observations in the letters to further contestation. In this sense it is curious that Mitzi Meyers should argue that 'Wollstonecraft's autobiographical account of her journey in some ways resembles Wordsworth's later pilgrimage in search of a reintegration of self, nature and society', thus figur- 
ing the Scandinavian letters as a 'revelatory psychological document'. ${ }^{15}$ I suggest that right from the outset Wollstonecraft specifically resists the overcoming of fragmentation and 'the power of the self to create unity', that Myers argues as necessary to the assertion of a Wollstonecraftian identity, through her critique of the egoistic boundaries of identity that would assert a self at the expense of the world and its others. ${ }^{16}$ As such the self in A Short Residence can be seen in distinct opposition to William Wordsworth's transcendental ego. Even as she approaches Sweden, Wollstonecraft emphasises an acute awareness of her own foreignness and marginality - something that she was already confronted with as a woman and public intellectual in British society.

The first letter, describing the passage from England and arrival on the coast of Sweden opens with a scene of dislocation and displacement as Wollstonecraft notes the unsuitability of the sailing vessel for the transportation of passengers. 'Eleven days', she writes, 'of weariness on board a vessel not intended for the accommodation of passengers have so exhausted my spirits ... that it is with some difficulty I adhere to my determination of giving you my observations, as I travel through new scenes'. ${ }^{17}$ Although she notes that her purpose is merely to observe, the sense of unease and exhaustion with which she begins her journey through Scandinavia suggests an unsettledness associated with her entry into another culture and another land, thus emphasising her marginality and effectively placing herself in question.

Although Favret argues to the contrary that Wollstonecraft arrives in Norway with 'courage and self-reliance' because she forces her 'will upon a weak captain and a reluctant crew' in order to commandeer a boat to shore, I suggest that the 'strength of character and easy relaxation' that Favret reads as setting the tone for the ensuing letters is destabilised significantly by the depiction of unease and exhaustion caused by the passage from England..$^{18}$ Although Wollstonecraft manages to convince the captain of the ship to let her go ashore despite missing their intended destination of Arendal, this does not give her a renewed sense of security or set her back on course because she arrives onshore at an unnamed destination marked only by 'the light-house'. ${ }^{19}$

The unease and disorientation that marks the opening of the letters foregrounds the notion of hospitality towards the foreign, both as a conditional form of everyday welcome and as a radical openness that places the self in question. Conditional hospitality is also introduced early in the letters when, after the threatening unfamiliarity of being lost somewhere off, and then on, the coast of Sweden, somewhere north of Elsinore, Wollstonecraft is understandably relieved to be welcomed into a little cottage whose master, as she later discovers, is a naval officer responsible for taking care of the bay. Her description of, albeit unfamiliar, homeliness nevertheless attests to the importance of being temporarily offered respite from the unease that pervades the early pages of the letters:

On entering [the cottage], I was still better pleased to find a clean house, with some degree of rural elegance. The beds were muslin, coarse it is true, but dazzlingly white; and the 
floor was strewn over with little sprigs of juniper (the custom, as I afterwards found, of the country), which formed a contrast with the curtains and produced an agreeable sensation of freshness, to soften the ardour of noon. Still nothing was so pleasing as the alacrity of hospitality. ${ }^{20}$

It is significant that this passage is framed with the action of moving towards others. In other words, the description of the first encounter with the Swedish inhabitants of the cottage near the lighthouse foregrounds her action of entering the private spaces of the naval officer's cottage with the reciprocity and quickness of response, the 'alacrity of hospitality'. Wollstonecraft's foreignness here is therefore not absolute, as it would be if it placed the self in question, because the contract of hospitality is marked by the open welcome afforded by the inhabitants. Nevertheless, the dual insistence on disorientation followed by a welcome emphasises these twin aspects of hospitality to the foreign as a primary theme in A Short Residence.

As Derrida explains, hospitality is not offered to the absolute stranger, to someone with no name and no social or familial status. ${ }^{21}$ The letters of introduction Wollstonecraft carries with her as Imlay's legal representative undoubtedly serve to legitimise her arrival in Scandinavia and her circulation within its various societies. They serve as the means by which a contract of hospitality allows Wollstonecraft to enter Scandinavia whilst protecting her against any possible risk of defilement, should she have entered Sweden as an absolute stranger. This of course is very similar to her concern in Rights of Woman that change brought about by a confrontation with difference be based upon the respect and equality inherent to the friendship relation.

Nonetheless, although there is clearly a contract of hospitality in place, one that allows Wollstonecraft to enter Scandinavia and to circulate, her openness to the new and the unknown nevertheless allows the absolute other to unsettle the self and to place it in question. At the same time, the contract places limitations on these modes of unsettling in order to safeguard against complete subjective annihilation and destruction. It is this twin movement of conditional hospitality, subject to the laws of the state, and the unsettling and destabilisation of unconditional hospitality (generated through openness and questioning) that pervades Wollstonecraft's particular epistemology in the Scandinavian letters.

Derrida, in his work on cosmopolitanism and forgiveness, argues that both the conditional and unconditional laws of hospitality must work together because without the former in place, the latter would become a 'pious and irresponsible desire, without form and without potency, to the extent of even being perverted at any moment'.22 The contradictory tensions evident in Wollstonecraft's Short Residence between the insistence of ethical openness and reciprocal contact on the one hand (the unconditional), and the commercial aims driving her journey on the other (the conditional), can thus be understood in Derridean terms as a form of the pure unconditional intervening in the conditional and delimited form of hospitality enabled by the contractual obligation. Whilst it is 
undoubtedly the case that Wollstonecraft's commercial venture delivers a determinate aim to her journey because its trajectory is configured according to the fulfilment of these aims, the letters disrupt these aims through their insistence on ethical openness as an opening to the mystery of the world and the possibility of change. It is curious then that Ty should read the various reflections on freedom in A Short Residence as a desire for self-care and self-protection. This would configure Wollstonecraft's engagements throughout her journey as primarily self-interested. ${ }^{23}$ As Nancy Yousef cogently argues, on the contrary, Wollstonecraft offers herself to otherness as an offering of the self in its vulnerability and despite her own disappointments over the failure of the French Revolution and the violence unleashed by Robespierre, as well as her personal disappointment over her failed relationship with Gilbert Imlay. ${ }^{24}$

The vulnerability that Yousef detects in the Scandinavian letters is foregrounded not only in the initial instance via the epistolary address, but similarly via Wollstonecraft's persistent questioning throughout her journey, as an open and non-directed inquisitiveness. This effectively resists the dictates of the singular ' $\mathrm{I}$ ' and any colonising imperatives associated with a self, and by implication with a nation, in pursuit of sovereignty. In the 'Advertisement', the preface to the book, Wollstonecraft apologises for the necessity of using the first person in her narrative, or what she calls, 'the little hero of each tale.'. ${ }^{25}$ Indeed she refers to the presence of the self as a fault, but notes that her attempts to correct this fault affected the writing in such a way as to make her letters too contrived. Several scholars have seen this apology as a deliberate strategy on the part of Wollstonecraft to draw attention to a personal intimacy that directs the reader to the private side of the letters. Favret argues that despite her explanation of the use of the 'I' as a device to gain the reader's interest, Wollstonecraft 'nevertheless draws attention to the personal sufferings and sorrows which the text of the Letters will not explain'. ${ }^{26}$

According to Favret the intimacy of the letters, generated by the use of the highly personal ' $I$ ', engenders audience identification with the narrator so that both can move 'from a nearly overwhelming sensibility toward a position of strength'. ${ }^{27}$ This mode of identification therefore draws the reader into the text, thereby breaking open any Rousseauvian self-enclosure in order to generate a space for personal exchange and relationship. Weiss similarly reads the use of the subjective viewpoint in the letters as an invitation to identification, whereby Wollstonecraft, in her suffering, 'invites the observing reader's sympathy and the masculine observer who pities suffering women'. ${ }^{28}$

Whilst these readings very poignantly point towards Wollstonecraft's careful inhabitation of feeling and reason as twin modes of social analysis, they nevertheless elide the simultaneous emphasis in the letters on the figuration of social and political improvement as dependent upon a resistance to the self-interested accumulation of power and property. Indeed Favret's reading of the 'little hero' apology as a 'de-personalizing device' nevertheless leaves a self intact as one axis of exchange. ${ }^{29}$ Even though Favret is right to point towards the way in which the 
apology creates a mode of reciprocity, I suggest that Wollstonecraft's resistance to self is more radical than these readings allow. In A Short Residence, Letter Eleven even goes so far as to imagine the disastrous effects of the egoistic drive in the form of ecological disaster:

I anticipated the future improvement of the world, and observed how much man still had to do, to obtain of the earth all it could yield. I even carried my speculations so far as to advance a million or two years to the moment when the earth would perhaps be so perfectly cultivated, and so completely peopled, as to render it necessary to inhabit every spot; yes, these bleak shores. Imagination went still further, and pictured the state of man when the earth could no longer support him. Where was he to fly from universal famine? ... I really became distressed for these fellow creatures, yet unborn. The images fastened on me and the world became a vast prison. ${ }^{30}$

This passage is remarkable for its Malthusian dystopic vision of massive overpopulation. Yet it is significant that the vision relies on an image of cultivation and appropriation of the earth's resources in such a way as to become massively unsustainable. Over-cultivation and lack of consideration for and attention to the ground of cultivation effectively turns back on man with the creation of 'universal famine'. Here Wollstonecraft shows that she is acutely aware of the social and ecological dangers of selfish accumulation. In this sense, it is curious that Angela Keane should read this description of eco-disaster as evidence of a pathological imagination, with powers of generation 'beyond the control of reason'.31 If there is an imagination that is pathologised here, it is one that works in concert with a selfish accumulative desire that would colonise and cultivate the earth to such an extent that its resources could no longer support human life. The world as a 'vast prison' is not engendered by the imagination, but rather by Wollstonecraft's use of reason as a means of predicting the logical outcome of selfish accumulation.

Throughout A Short Residence, Wollstonecraft is consistently critical of modes of delineating the self, either the individual self or the national self, in ways that close off open discussion, contact with others, and the productive transformations brought about by difference. Letter Five counterposes the process of inquiry and discussion against what Wollstonecraft describes as the 'dogmatical assertions' of authoritarian tyranny that aim only to 'gird the human mind' by constricting thought with suppositions that are little more than constructed, and thus arbitrary, fictions, or, as Wollstonecraft puts it, 'imaginary circles'. ${ }^{22} \mathrm{By}$ contrast then, the spirit of inquiry as the asking of questions, rather than the assertion of answers, leans towards the future as a means of disrupting both the illusion of racial and national stereotypes as well as the ignorance of difference. Imagination and the potential to be otherwise, to change society and avoid the horrors that Wollstonecraft witnessed during the French Revolution, are thus located within the very space of the unknown that questioning teases open. This is a space that is, moreover, closed off by the insistence on selves and nations as sovereign and self-enclosed. 
Undoubtedly, we may question whether her legitimated position as Imlay's legal representative and her mission in the service of capitalist enterprise allows Wollstonecraft to feel, as Richards suggests, more secure in her vulnerability and her openness to others. Yet at the same time, Wollstonecraft's persistent vitriol against self-enclosed sovereignty and the acquisition of property de-legitimates, or at least destabilises, this authorised position. In Letter Nineteen she refers to an 'adoration of property' as the 'root of all evil',33 and in Letter Twenty-Two suggests that even charity is inscribed within the system of property relations through its offering not as pure gift, as Derrida would have it, but rather as a contractual obligation of return. As Wollstonecraft writes:

You know I have always been an enemy to what is termed charity, because timid bigots endeavouring thus to cover their sins, do violence to justice, till, acting the demi-god, they forget they are men. And there are others who do not even think of laying up a treasure in heaven, whose benevolence is merely tyranny in disguise: they assist the most worthless, because the most servile, and term them helpless only in proportion to their fawning. ${ }^{34}$

The egocentric delivery of charity as a contract dependent upon the servility of those less fortunate is here aligned with a tyrannical drive for power. This is quite a different form of contract from the reciprocal coming together that Wollstonecraft describes on entering the naval officer's cottage when she first arrives in Sweden. The giving of alms as a contractual obligation is denoted by Wollstonecraft as doing 'violence to justice' and as 'tyranny in disguise' because the charitable act is configured as little more than a form of self-justification and the false appropriation of power over others. Charity is in this case, according to Wollstonecraft, given only in the interests of the sovereign self in the same way that selfish accumulation and over cultivation of the earth's resources lead to the possibility of ecological disaster in the form of famine. Both forms of relation with others (the earth and the poor) are unjust, in other words, because those others are not considered within the terms of an equal relation of reciprocity and freedom - something that Wollstonecraft believes is the natural right of human being.

Throughout A Short Residence, the critique of sovereignty and contractual obligation as modes of tyranny and domination finds its apotheosis in Wollstonecraft's criticisms of the merchants and businessmen she encounters during her journey, most notably in Copenhagen and Hamburg. According to Wollstonecraft the problems attending charity as an obligation of (moral) debt and the self-interested acquisition of property that results in her vision of dystopian ecological disaster both result in the kind of paranoia she sees as intrinsic to a society founded on property-relations and circulated by the mechanisms of commercial enterprise. The merchants in Hamburg are described as constantly on guard against others, suspicious of their Danish neighbours, and, as she writes, 'anxiously apprehensive of their sharing the golden harvest of commerce ... they 
are ever on the watch till their eyes lose all expression, excepting the prying glance of suspicion'. 35

The focus here on anxious watching, suspicious glances and expressionless eyes implicates vision as the means of perception most antithetical to Wollstonecraft's notion of justice as an opening towards the other. As Anthony Pollock astutely notes, the two primary bases of Wollstonecraftian ethical action are familiarity and hospitality. ${ }^{36}$ The Hamburg merchants ensure they can never get to know their Danish neighbours because the latter are constantly subjected to a paranoid surveillance that reifies the distance between the two groups as an insurmountable border.

Favret suggests that Wollstonecraft opposes the work of the imagination, which is figured as distinctly feminine, to this masculine and de-humanising world of commerce in order to prove 'the productive power' of the former. ${ }^{37}$ According to Favret the criticism of commerce in A Short Residence is somewhat ironic, given that Wollstonecraft subsequently profits, with the publication of her letters, from this same system. The elevation of the 'power of the female imagination' would effectively destroy the open reciprocity of hospitality due to its infinite desire to appropriate experience for the sake of productivity. And yet openness to the foreign, and to difference, is intrinsic to the Wollstonecraftian notion of ethical engagement pervading both the Scandinavian letters as well as her earlier political treatises. As Derrida argues, absolute hospitality requires not only opening one's home, and by implication one's self, to the foreigner with a name and with papers, but also to 'the absolute, unknown, anonymous other'. It requires that 'I give place to them, that I let them come, that I let them arrive, and take place in the place I offer them, without asking of them either reciprocity (entering into a pact) or even their names. The law of absolute hospitality commands a break with hospitality by right, with law or justice as rights'. ${ }^{38}$

The selfish greed of commercial enterprise, together with its objectification of others, is depicted throughout the Scandinavian letters as an effacement of the sympathetic engagement with and ethical openness to others necessary for Wollstonecraft's vision of social improvement. In this sense, I think that critics of A Short Residence who read the letters as an expression of female desire miss the point primarily because Wollstonecraft takes such care to insist upon the unfeeling distance created by the economies of desire and pleasure intrinsic to the perpetuation of commerce and trade. In the Scandinavian letters, the blind ignorance to others, in their difference and in their suffering, finds its apotheosis in the perverted pleasures of witnessing an execution as a spectacle for enjoyment. The critique of the Copenhagen businessmen in Letter Eighteen is soon followed by a scene, at the beginning of Letter Nineteen, in which Wollstonecraft travels to the outskirts of Copenhagen and is shocked to observe the vicarious pleasures of a crowd enjoying the brutal execution of a criminal. Her distress at the scene of events rests primarily in the way that the crowd treats the execution and subsequent burning of the corpse as a theatrical event, divested of humanity and any sympathy for the condemned man. Wollstonecraft declaims the event as 
'a spectacle for humanity', and then goes on to write that 'executions ought to have every appearance of horror given them; instead of being, as they are now, a scene of amusement for the gaping crowd, where sympathy is quickly effaced by curiosity. ... people go to executions to see the poor wretch play his part, rather than to commiserate his fate, much less to think of the breach of morality which has brought him to such a deplorable end'. ${ }^{39}$

Although Wollstonecraft does not suggest that the crowd's insensitive and unreflective witnessing of the execution is a direct consequence of the egoistic accumulation of commerce and its blindness towards the condition of others, she describes both the scene of execution and the behaviour of the Copenhagen businessmen in similar terms. The indifference towards others generated by the desire for pure pleasure in the moment, either in the witnessing of violence as spectacle or in the pursuit of desirable objects, is depicted by Wollstonecraft as a perversion of justice through its destruction of sympathy and understanding for the suffering of others. In this sense, feeling is shown to be, in its absence from the crowd of spectators, a means of contact that would effectively place the self in question by opening it out towards otherness.

\section{Contact}

Throughout A Short Residence, sensuous or sympathetic engagement with others, in concert with rational reflection, disables the spectacularity underwriting mercantilism and the institution of artificial national and sovereign borders - that is, everything that keeps us at a distance from the world and its others, and everything that reifies otherness into a commodity for subsequent circulation within a system of exchange. As I discussed earlier, the opening of A Short Residence is marked by a description of unease (the unsuitability of the sailing vessel for personal transport) and losing one's way (in the storm), as well as an apology for using the narratorial ' $\mathrm{I}$ '. This immediately foregrounds Wollstonecraft's resistance to the dictates of the colonising imperative, even if at times there are traces of an imperialist superiority in the letters, for example in her comment on indiscriminate hospitality as a ruse for drunkenness in Dublin. Yet, any claims of superiority in the service of a sovereign self or sovereign (British) nation are unravelled by Wollstonecraft's anti-heroic insistence on self-expropriation.

Letter Two immediately marks the importance of deference to the relational encounter with a request for admission: 'let me, my kind strangers, escape sometimes into your fir groves, wander on the margin of your beautiful lakes, or climb your rocks to view still others in endless perspective'. $4^{\circ}$ This request for permission to enter the land of strangers (in this case, Sweden) is foregrounded with images of self-disappearance and marginality. Wollstonecraft writes of her wish to escape into the depths of fir groves, to circle the margins of the lakes, and to climb rocky outcrops, where she does not expect to survey the lands but rather to become lost in the 'endless perspective' of similar rocks.

Not only is Wollstonecraft intensely aware of her own marginality and for- 
eignness as she enters Sweden, she insists nevertheless upon remaining open to the environment. The scene that closes Letter Two, and that follows the request for permission to enter the land, describes an extraordinary encounter with the world around her:

The cow's bell has ceased to tinkle the herd to rest; they have all paced across the heath. Is not this the witching time of night? The waters murmur, and fall with more than mortal music, and spirits of peace walk abroad to calm the agitated breast. Eternity is in these moments: worldly cares melt into the airy stuff that dreams are made of; and reveries, mild and enchanting as the first hopes of love, or the recollection of lost enjoyments, carry the hapless weight into futurity, who, in bustling life, has vainly strove to throw off the grief which lies heavy at the heart. Good night! A crescent hangs out in the vault before, which woos me to stray abroad: - it is not a silvery reflection of the sun, but glows with all its golden splendour. Who fears the falling dew? It only makes the mown grass smell more fragrant..$^{1}$

Although this passage describes a pleasing escape into eternity, where 'worldly cares melt into the airy stuff that dreams are made of', the observation is framed by the materiality of existence, figured as magical, or bewitching, due to Wollstonecraft's ability to sustain connection with and openness to it. In other words, the importance of going outside and feeling the 'falling dew', or the rain on our faces, is that it keeps us alive to the existence of the world in its material transformations. As Sara Mills argues, Wollstonecraft figures the landscape as a 'relational zone' in which she poses herself 'as an experiencing subject, but not one who is intent on focusing, controlling, and limiting her emotions'. According to Mills this configures the perceiving self of the narrator as 'an element within the spatial dynamics' of the scene. ${ }^{42}$

This immersive self cannot possess or control others because it has been in the first instance deferred in the request for permission in the same way that the letters defer control over outcomes in the epistolary form of their address to an unnamed reader, even if we presume to know who this reader might be. Secondly, this self is shown to be generated from the interweaving of critical reflection and sensuous experience. It is the quiescence of the cow's bell and the murmuring of the waters that gives rise to Wollstonecraft's reflections on eternity as being held in the small moments of the here and now. Moreover, it is only after the return to the silvery night of the crescent moon hanging in the 'vault' of the sky that the subject emerges to be drawn forward, 'to stray abroad' and to enter the world in its strangeness and difference, without fear, but with acute attention to the transformative experiences enabled by contact with that world. Rather than fear the falling dew, Wollstonecraft suggests we should be open to the way it can make the 'mown grass smell more fragrant'.

Christine Chaney suggests that the mode of narration in A Short Residence is intensely confessional, because Wollstonecraft offers her experience as 'the ultimate proof of her theories about the importance of education, genius, and 
independence for women'. ${ }^{43}$ Elizabeth Bohls similarly argues that the Scandinavian letters, in contrast to the impersonality of much eighteenth-century travel writing, exhibit a highly subjective persona through Wollstonecraft's episodic descriptions of highly subjective states of being. ${ }^{44}$ Whilst it is certainly the case that following the Reign of Terror, as Dart notes, many leading figures in France wrote confessions as justifications of their political conduct, Wollstonecraft was not under the same threat of imprisonment and death as French intellectuals such as Brissot, Roland, and Louvet, even though she had resided in France during the summer of 1793 when the Jacobins called for the arrest of many of her Girondin friends. ${ }^{45}$

Although I agree that A Short Residence offers its observations on the land, life, and customs of Scandinavia through descriptions that seem at times to be intensely personal, I suggest that Wollstonecraft offers a self that is contextual and singular, rather than a self that is revealed through acts of disclosure associated with a confessional mode. The latter would assume a contained and self-enclosed subject that is revealed through the narrating of self-in-confession, whereas the contextual self is formed within the interstices of world and thought, and of sensuous experience and critical reflection. This is precisely what gives rise to the subject at the end of Letter Two. The narratorial voice appears in the midst both of a landscape intensely alive with sound and movement, and within a moment of history that reaches simultaneously back into the past and forwards into futurity. This does not, nevertheless, disable what Chaney refers to as the production of a 'dialogic interaction that invites the answering and competing discourse of its reader'. ${ }^{6}$ Rather it insists upon dialogic interaction as the result of sketching what Anne Dufourmantelle, in her response to Derrida, describes as 'the contours of an impossible, illicit geography of proximity.'47

This geography of proximity is impossible because in delineating the self as contextual, and as generated from the contours of direct experience in the world, it must necessarily be open to the unknown, the excessive and the radically alterior, that is, without fear of the 'falling dew' and the transformations it engenders. As Wollstonecraft writes towards the end of A Short Residence, 'The world cannot be seen by an unmoved spectator; we must mix in the throng and feel as men feel, before we can judge of their feelings'. ${ }^{4}$

In contrast to the violent non-encounters Wollstonecraft describes as generated through surveillance and spectacularity, her mode of engagement with the world is distinctly non-proprietary. In her letter from Tønsberg, she describes a rowboat excursion in which she encounters a shoal of young starfish floating just below the surface of the water:

I had never observed them before; for they have not a hard shell, like those which I had seen on the sea-shore. They look like thickened water, with a white edge; and four purple circles, of different forms, were in the middle, over an incredible number of fibres, or white lines. Touching them, the cloudy substance would turn or close, first on one side, then on 
the other, very gracefully; but when I took one of them up in the ladle with which I heaved the water out of the boat, it appeared only a colourless jelly.49

The sense of wonder and surprise at encountering these creatures is held in concert with the sense of inquiry directing the encounter. Rather than being driven by a desire for possession, the scene is one of engagement as mutual. Wollstonecraft notes that she touches the creatures so that they 'turn or close' and that this response to her touch is one of incredible grace. Although the process is directed by vision, it is supplemented and extended via touch as direct engagement rather than pure observation. Both are shown to be important in the process of Wollstonecraftian inquiry. Furthermore the care that is suggested by the action of scooping up one of the starfish in her ladle, as if cupping them in open hands, gestures towards a reciprocal action of mutual engagement underwriting the entire process of observational inquiry.

Although the narratorial self in the starfish passage does not emerge from the crossing between sense and experience as it did at the end of Letter Two, the self is here very clearly immersed in the world she is observing, as a part of that world, engaged with and in dialogue with that world. Bohls reads this passage in particular as a parable of localism in that the beauty and grace that Wollstonecraft attributes to the 'humble organism, the "star fish" or "jelly-fish"' is a beauty that depends on its local environment, because when removed from the water, the fish becomes an unappealing mass of flesh. ${ }^{50}$ The starfish passage from Tønsberg is, according to Bohls, one example of many incidents throughout A Short Residence that all variously place an emphasis on immersion within and direct experience of the local environment as intrinsic to Wollstonecraft's distinct form of epistemology. ${ }^{51}$ It is for this reason that Wollstonecraft suggests in Letter Nineteen that travelling should form an essential component within any liberal education and that 'the northern states' should be visited before what were generally thought of as 'the more polished parts of Europe, to serve as the elements even of the knowledge of manners, only to be acquired by tracing the various shades in different countries'.52

It is undoubtedly the case that Wollstonecraft understands social progress through a distinctly Enlightenment framework, upholding 'personal cleanliness and elegance of manners which only refinement of taste produces' as markers of social progress, and thereby inadvertently upholding British values in the process. ${ }^{53}$ Yet the insistence on appreciating and being open to variations in manners and customs in different countries, and in 'tracing' these differences beyond the countries normally visited on the standard itinerary of the Grand Tour, necessarily complicates the meaning of 'elegance of manners' and 'refinement of taste' because these would be subject to the various shades they acquire, when contextualised within their local environments and particular histories - both of which I have already argued are important to Wollstonecraft's conception of knowledge as embedded. 
As Wollstonecraft writes in Letter Five: 'Travellers who require that every nation should resemble their native country, had better stay at home'. ${ }^{54}$ It is not enough, in other words, to be drawn to foreign lands in order to make observational judgements on their people and cultures because this kind of knowledge needs to be gained through contact and direct experience, and moreover, with an awareness of and openness to the differences that are encountered in foreign environments.

\section{Conduit}

The making of a space for difference in A Short Residence through the tracing of 'various shades in different countries' allows the alterity of otherness to be preserved because, as Pollock argues, the scene/seen is allowed to present itself via the subject who acts as a conduit for a 'just description'. It is a process, according to Pollock, that 'does justice to the object of observation through the scrupulous and self-implicating act of merely describing it'.5 This kind of 'just observer', or what Pollock refers to as the 'ideal spectator', is one that I suggest not only preserves the alterity of otherness through a resistance to knowledge as possession, it simultaneously insists that an ethical spectatorship must occur in conjunction with other forms of sensuous experience, such as tactile response for instance. In this sense, what Scott Juengel refers to as Wollstonecraft's 'sympathetic ecology' demands an emphasis on mutual engagement, whilst recognising the epistemological limits to knowledge. ${ }^{56}$ This is important because the self that is then offered to the other through the process of engagement, in the act of inquiry, is a self that is offered to an otherness that cannot be known. As Nancy Yousef has cogently remarked, this is a self that is offered in its vulnerability, despite an acute awareness of the human capacity for doubt and betrayal..$^{57}$

In this sense, it is curious that Yousef should configure Wollstonecraft's need to be heard and to be loved as a demand for recognition and thus a dependency on the other (the addressee of her letters or the readers of her book). In fact I would argue that her very insistence on the gift of self as a form of ethical justice disables the structures of recognition inherent to the antagonistic relation between parent and child evident in the kind of charity that Wollstonecraft derides as self-interested egotism, and which Catherine Belsey describes as particular to the colonial project. ${ }^{8}$

The notion of justice as ethical relation, and in distinct contrast to justice as dogma, is one that pervades Wollstonecraft's entire oemvre, both in the Scandinavian letters as well as, and perhaps more so, in her political treatises. Her insistence on the importance of cultivation, most notably in the attention she gives to family and education as the basis of a just society, configures an idea of justice that is impossible without the simultaneous notion of relation, or of self in relation. Daniel Engster refers to this idea of justice as belonging to the framework of care theory, that is, as a shift from justice intended to mediate human relationships by applying abstract moral principles to particular cases, to a jus- 
tice focused on the needs of individuals and the attempt to address these needs in context. ${ }^{59}$ Indeed Wollstonecraft depicts the self-in-relation, as a self that is not only contextual but also respects the otherness of radical difference, as the basis of a justice she sees as inherently ethical.

For Wollstonecraft, justice takes place between the demands of contextual emplacement and cultivation on the one hand, and the demands of critical reflection on the other. The ability to make judgments and to resist being overtaken by submission to the passions nevertheless remains important, because, as was acutely evident in Rights of Woman, the strength of a delicate intellect, so important to a society of equals based in friendship, relies on the fine balance of sympathetic engagement and critical reflection. Wollstonecraft's sometimes harsh judgements against those she encounters during her Scandinavian travels are generally made on the same grounds as her criticisms of British society. Her disgust with the artificial manners of the Swedish aristocracy in Stockholm repeats her gender and class-based critique of British society in Rights of Woman. Accordingly, when she argues in A Short Residence for 'joining the advantages of cultivation with the interesting sincerity of innocence' as a means of countering the artificiality of aristocratic life, she is directing her critique against the social and political systems she sees as responsible for the inequalities of society, rather than against an essentialised natural or ethnic difference. ${ }^{60}$ In this respect Dart is right to note that for Wollstonecraft an ideal society is 'a realm of free inquiry, a site of open debate and discussion, a highly 'civilized' place'. ${ }^{6 r}$

However, his simultaneous claim that Wollstonecraft exploits her emotional isolation in order to 'indulge a fantasy of herself as a Rousseauvian législateur ... a disinterested lawgiver' cannot be supported by a text in which the demands of Wollstonecraft's own version of ethical justice as hospitality to otherness and to difference must themselves be open to the potential destabilisations of contextualisation and interrogation. ${ }^{62}$ In other words, the insistence on open discussion as a means of allowing difference to enter ensures that any critique must be able to withstand the forces of subsequent critique and possible transformation, as it is reapplied to differing temporal and geographic circumstances, and thus opened to the destabilisations of the new and the different.

For Wollstonecraft, the importance of receptiveness to the mystery of radical otherness is that it has the power to afford a glimpse of bare existence, beyond the strictures of state and juridical power, and therefore to engender communities of engagement beyond identity. It is ironic therefore that Wollstonecraft should close her critical assessment of Swedish gender and class differences in Letter Four with a description of the face-to-face encounter as affording such a glimpse. As she writes, 'I love sometimes to view the human face divine, and trace the soul, as well as the heart in its varying lineaments. ${ }^{63}$ This remarkable line locates the divine and the transcendent within the encounter of the face-to-face, where, as Levinas writes in another context, 'face to face, I can no longer deny the other: it is only the noumenal glory of the other that makes the face to face situation possible. The face to face situation is thus an impossibility of denying, 
a negation of negation'. ${ }^{64}$ As Levinas argues, and as Wollstonecraft illustrates, the face to face encounter allows us to resist a hierarchical world where justice is the dogmatic institution of universal principles. For Wollstonecraft, the face allows one to glimpse something beyond the dictates governing the everyday construction of identities (individual, communal, and national) such that its impact in the moment of perception, as an encounter between two beings suddenly taken out of the everyday world of society and politics, becomes a means of generating her particular vision of ethical justice.

The insistence on knowledge as singular and contextual, glimpsed in the moment of the direct encounter, such as that governing the face-to-face, permeates Wollstonecraft's political project across her entire oewvre. Moreover, I suggest that her insistence on the anti-heroic and the unexceptional similarly informs the deliberate invocation by Wollstonecraft of a mode of perception in A Short Residence that Bohls refers to as the 'anti-aesthetic', and which effectively situates the aesthetic within the practical as a 'corporeally and politically situated mode of perception'. ${ }^{65}$ According to Bohls, this mode of perception emphasises the continuities between the practical conditions of everyday life and the quality of the life that is achieved within those conditions. Rather than seeing local residents, such as rural Scandinavians, with the distancing effect of the conventional aesthetic framework, Bohls suggests that in A Short Residence Wollstonecraft creates the materially grounded quality of their lives in such a way as to open a space for the dignity of the poor to be reaffirmed, and their 'corporeally grounded needs' to be validated ${ }^{66}$ In other words, by placing the labouring body of the Swedish peasant within the context of his or her local environment, Wollstonecraft creates the material conditions for us as readers to empathise with the plight of those labouring bodies. She draws us, as readers, into the networks of responsiveness engendered by the dynamics of ethical justice as hospitality and openness.

The glimpse of humanity as bare existence, beyond the confines of identity categories and the laws of the state, functions for Wollstonecraft not only as a gesture towards the divine (in the face-to-face encounter). It similarly functions as a stark reminder that death returns material and worldly existence, upon which claims of property and sovereignty are based, to the grave. This realisation in fact forms the basis of her encounter in Letter Seven with the embalmed bodies housed in the small Norwegian church. Wollstonecraft is horrified at the attempt to preserve the body after death, when it is, as she writes, 'deprived of life, and thus dried into stone'. ${ }^{67}$ The corpses, reified into stone, disallow any encounter with the wonder and mystery of life beyond identity. Instead they graphically illustrate what seems to her the pointlessness of struggles over excessive power and wealth in the material world of the here and now, that is, beyond the necessities needed to sustain life. As Wollstonecraft declaims: 'Is this all the distinction of the rich in the grave? - They had better quietly allow the scythe of equality to mow them down with the common mass, than struggle to become a monument of the instability of human greatness' ${ }^{\prime}{ }^{6}$ The grotesquerie of the embalmed bodies is depicted here as an inversion of power and wealth because the bodies, petrified 
in a half-decayed ugliness, only prove the 'instability of human greatness' rather than its continuance in the after-life.

The glimpse of humanity as bare existence, occluded in the practice of embalming bodies after death, but glimpsed through an open responsiveness to otherness in life, is one that, according to the framework of Wollstonecraftian ethical justice, provides the momentum for change because it instils a responsibility, as response-ability, that both precedes and exceeds the self. This means that the response can be offered, just as Wollstonecraft offers her observations, only as examples. As Alex Thomson argues in his work on democracy and deconstruction, 'if they were prescriptions our responses would be irresponsible, and would conform to a rule' ${ }^{69}$ Social change through violent revolution is what Wollstonecraft wants to avoid. The murderous excesses of the French Revolution and Robespierre's subsequent Reign of Terror proved to be horrifying examples of justice enacted on abstract principles and unsympathetic grounds. For this reason Wollstonecraft insists in the appendix to her letters that change should be 'a gradual fruit of the ripening understanding of the nation, matured by time, not forced by an unnatural fermentation'. ${ }^{\circ}$

A Short Residence is indeed permeated with a faith that human prejudice can eventually be destroyed with the cultivation of an ethical respect for the various nuances and shades of difference that exist between individuals, as well as a receptiveness and responsiveness to the glimpse of bare existence afforded through direct contact with others and with the mystery of radical otherness. Politics, when subjected to the demands of ethical justice, thus becomes not simply a mode of response-ability, figured as always necessarily subject to the contingencies of the contextual. It also becomes, in the words of Thomson, 'a challenge made to the limits of the state, in the name of what lies beyond the state, and perhaps beyond the field of politics and law as we usually define them'. ${ }^{71}$

A Short Residence in Sweden, Norway and, Denmark is arguably the most accomplished of Wollstonecraft's books for its complex interplay between critical reflection and sympathetic engagement. It depicts a notion of understanding not as something that is achieved, but as something that cannot be separated from the contingencies of space and time, nor from the demands of a responsive and non-appropriative engagement with alterity. As such, Wollstonecraftian ethical justice comes to be figured as a process of constant reappraisal through which gendered or national identities can be contested and remade. This engenders an openness not only to the conditions of the present, but also to the unknown of the future, to the demands of a response-ability to the unknown other. Indeed for Wollstonecraft, 'the future improvement of the world' depends upon this very response-ability as responsibility, that is, as the gift of self to the unknown future, and specifically, the gift of self to what she describes as 'these fellow creatures yet unborn'. ${ }^{2}$ 


\section{Notes}

1 Richard Holmes notes in his introduction to A Short Residence that Imlay had been involved with his contacts in Scandinavia and Hamburg in a practice known as 'blockade-running', whereby a lighter weight sailing vessel is used to evade a navy blockade. Mary Favret adds to this observation that Imlay had expected a 'doubly treacherous exchange' and therefore sent Wollstonecraft to act as his legal representative in a suit taken against the ship's captain. See Richard Holmes, 'Introduction', A Short Residence, by Mary Wollstonecraft (London: Penguin Classics, 1985), 22; and Mary Favret, Romantic Correspondence: Women, Politics, and the Fiction of Letters (Cambridge: Cambridge University Press, 2005), 98.

2 Favret, Romantic Correspondence, 113-4.

3 Ibid., 115.

4 Gregory Dart, Rousseau, Robespierre and English Romanticism. (Cambridge: Cambridge University Press, 2005), 134 .

5 Mary Wollstonecraft, A Vindication of the Rights of Woman (1792; repr., London: Penguin Classics, 1985), 130-1.

6 Eleanor Ty, ' "The History of My Own Heart”: Inscribing Self, Inscribing Desire in Wollstonecraft's Letters from Norway', in Mary Wollstonecraft and Mary Shelley: Writing Lives, ed. Helen M. Buss, D. L. MacDonald, and Anne McWhir (Waterloo: Wilfrid Laurier University Press, 2001), 70,73 .

7 Jeanne Moskal, 'The Picturesque and the Affectionate in Wollstonecraft's Letters from Norway', Modern Language Quarterly 52, no. 3 (September 1991): 276, 285.

8 Deborah Weiss, 'Suffering, Sentiment, and Civilization: Pain and Politics in Mary Wollstonecraft's Short Residence', Studies in Romanticism 45 (Summer 2006): 220.

9 William Godwin, Memoirs of the Author of 'The Rights of Woman' (1798; repr., London: Penguin, 1987), 249.

10 Ty, 'The History of My Own Heart', 76.

11 See Cynthia Richards, 'Fair Trade: The Language of Love and Commerce in Mary Wollstonecraft's Letters Written During a Short Residence in Sweden, Norway, and Denmark', Studies in Eighteenth Century Culture, 30 (2001): 71-89; and Raoul Grandqvist, 'Her Imperial Eyes: A Reading of Mary Wollstonecraft's Letters Written During a Short Residence in Sweden, Norway and Denmark', Moderna Sprak 91 (1997): 16-24.

12 Jacques Derrida, Of Hospitality: Anne Dufourmantelle Invites Jacques Derrida to Respond, trans. Rachel Bowlby (Stanford: Stanford University Press, 2000), 5 (italics in the original).

13 Ibid., 3.

14 Ibid., 147-9.

15 Mitzi Meyers, 'Mary Wollstonecraft's Letters Written ... in Sweden: Toward Romantic Autobiography', Studies in Eighteenth-Century Culture 8 (1979): 166.

16 Ibid., 173.

17 Mary Wollstonecraft, A Short Residence in Sweden, Norway, and Denmark. (1796; repr., London: Penguin Classics, 1987), 63.

18 Favret, Romantic Correspondence, 103.

19 Wollstonecraft, A Short Residence, 64.

20 Ibid., 66 
22 Jacques Derrida, On Cosmopolitanism and Forgiveness, trans. Mark Dooley and Michael Hughes (London and New York: Routledge, 2001), 23.

23 Ty argues that Wollstonecraft is moved by the kindness of strangers because she desires someone who can sympathise with and care for her. See Ty, 'The History of My Own Heart', 78.

24 Nancy Yousef, 'Wollstonecraft, Rousseau and the Revision of Romantic Subjectivity', Studies in Romanticism 38, no. 4 (Winter 1999): 537-57. Wollstonecraft, A Short Residence, 62.

26 Favret, Romantic Correspondence, 127-8. Ibid., 108.

28 According to Weiss, this use of sentiment as a means of identification is a deliberate strategy whereby 'women's pain becomes a source of intellectual accomplishment' such that feeling and thinking together enable women to be transformed into 'agents of progress'. See Weiss, 'Suffering, Sentiment, and Civilization', 103. Press, 2000), 126 craft's Letters from Sweden', The Eighteenth Century 52, no. 2 (2011): 198

37 Favret, Romantic Correspondence, 120.

38 Derrida, Of Hospitality, 25 (italics in the original).

39 Wollstonecraft, A Short Residence, 168-9.

40 Ibid., 74 .

41 Ibid., 75

42 Sara Mills, 'Written on the Landscape: Mary Wollstonecraft's Letters Written During a Short Residence in Sweden, Norway and Denmark', Romantic Geographies: Discourses of Travel 1775-1844, ed. Gilroy Amanda (Manchester: Manchester University Press, 2000), 29, 30.

43 Christine Chaney, "The Rhetorical Strategies of "Tumultuous Emotions": Wollstonecraft's Letters Written in Sweden', Journal of Narrative Theory 34, no. 3 (2004): 288.

44 Elizabeth Bohls, Women Travel Writers and the Language of Aesthetics 1716-1818 (Cambridge: Cambridge University Press, 1995), 159.

45 My problem with Dart's reading of the confessional mode in Wollstonecraft's A Short Residence as a manipulation of the personal in the service of the political is that a good deal of his justification for the influence on her writing of other (primarily French) writers is based on speculation. In fact we do not know whether Wollstonecraft was as struck by the use of first person narration by Roland and Louvet as Dart speculates. Neither does Dart give any evidence to suggest that Wollstonecraft was so impressed with the techniques of Rousseau's confessional mode that she chose to emulate him. See Rousseau, Robespierre and English Romanticism, 123, 131.

46 Chaney, 'The Rhetorical Strategies of "Tumultuous Emotions" ', 295. 
In Derrida, Of Hospitality, 2.

48 Wollstonecraft, A Short Residence, 219.

49 Ibid., 112.

50 Bohls, Women Travel Writers and the Language of Aesthetics, 166.

51 Bohls similarly reads this emphasis on localism in the way that Wollstonecraft places peasants within their local environments, and in her insistence that aesthetic pleasures must similarly be contextualised amongst other sensual pleasures, rather than treated as divorced from and therefore superior to them. Wollstonecraft, A Short Residence, 173. Ibid., 93.

54 Ibid.

55 Pollock, 'Aesthetic Economies of Immasculation', 200.

56 Scott Juengel, 'Countenancing History: Mary Wollstonecraft, Samuel Stanhope, and Enlightenment Racial Science', ELH 68, no. 4 (Winter 2001): 912.

57 Yousef, 'Wollstonecraft, Rousseau and the Revision of Romantic Subjectivity', 540.

58 See Catherine Belsey, Desire: Love Stories in Western Culture (Chichester: Blackwell, 1994).

59 Daniel Engster, 'Mary Wollstonecraft's Nurturing Liberalism: Between an Ethic of Care and Justice', American Political Science Review 95, no. 3 (2001): 577.

60 Wollstonecraft, A Short Residence, 84.

61 Dart, Rousseau, Robespierre and English Romanticism, 132.

62 In fact Dart gives very schematic evidence to support his claim that Wollstonecraft instantiates the Rousseauvian législateur in the Scandinavian letters. He makes this claim by mapping Rousseau's presentation of a state of nature, in which the solitary legislator feels truly at home through its depiction as a realm in harmony with his or her own internal nature, onto Wollstonecraft's own engagements with the Scandinavian landscape. However as many scholars have already noted, Wollstonecraft, in a manner quite different from Rousseau's solitary wanderer, always turns back to the social and to the human. See Rousseau, Robespierre and English Romanticism, 132-3.

63 Wollstonecraft, A Short Residence, 84.

64 Emmanuel Levinas, Entre Nous: Thinking-of-the-Other, trans. Michael Bradley Smith and Barbara Harshav (London: Continuum, 2006), 30.

65 Bohls, Women Travel Writers and the Language of Aesthetics, 142.

66 Ibid., 158.

67 Wollstonecraft, A Short Residence, 109.

68 Ibid.

69 Alex Thomson, Deconstruction and Democracy (London: Continuum, 2005), 100.

70 Wollstonecraft, A Short Residence, 198.

71 Thomson, Deconstruction and Democracy, 95.

72 Wollstonecraft, A Short Residence, 130. 